\title{
Ages of Commerce in Southeast Asian History
}

\author{
David Henley
}

Fernand Braudel classically proposed three interlocking historiographic time frames: the 'history of events', the history of cycles, and the longue durée or long duration (see this volume, Chapter 1). As an example of cyclic historical change, Braudel (1960:5) cited the fifty-year cycle of rising and falling prices identified in European history by the economist Nikolai Kondratiev. In Southeast Asian history, as Boomgaard (2002) has shown, the Kondratiev cycle is only of late and limited significance. In recent literature, however, another, much longer and more important economic cycle has emerged in the historiography of Southeast Asia: an epic succession of centuries-long 'ages of commerce', separated by trade depressions lasting many decades. Although approximately cyclic, the chronological scale of this phenomenon seems to put it firmly in the realm of Braudel's longue durée, as do the profound political and cultural consequences which some writers have ascribed to it. The present chapter provides a brief critical survey of the development, implications, and limitations of the Age of Commerce paradigm.

Not so long ago, the history of commerce in Southeast Asia was for most purposes equated with the history of colonialism. Money and trade were seen essentially as one component of a great Western assault - economic, political and cultural - on 'traditional' Southeast Asian societies that began in the sixteenth or seventeenth century, and led ultimately to the nationalist reaction of the twentieth (Boeke 1953:67-86; D. Hall 1955:649-671). It was Europe which, with a little help from Chinese 'middlemen', had intruded upon and broken open Southeast Asia's age-old self-sufficiency. In this view, epitomized by B.J.O. Schrieke's memorable declaration (1955-57, II:100) that 'the Java of around $1700 \mathrm{AD}$ was in reality the same as the Java of around 700 AD', a millennium of virtual stasis - in economic as in other spheres - was brought to a late, dramatic end by the accelerating rise of Western power in the eighteenth and nineteenth centuries.

Of course there was always a memory of the fact that the very earliest European interventions in the region, in the sixteenth and seventeenth centuries, had consisted of attempts either to extract parasitic profits from preexisting intra-Asian trade systems (as in the case of the Portuguese occupation of Malacca), or to destroy and supplant them (as in the case of the voc assault on the Moluccas). But scholars who had looked at this period tended to characterize the precolonial sea trade of Southeast Asia as a primitive 'peddling' of

(C) DAVID HENLEY, 2015 | DOI 10.1163/9789004288058_009

This is an open access chapter distributed under the terms of the Creative Commons Attribution-

Noncommercial 3.0 Unported (CC-BY-NC 3.0) License. 
luxury goods from port to port, having 'nothing in common with "bourgeois" commercial forms of trade' (Van Leur 1960:54-55). Compared with nineteenthcentury developments like the ruthless state-orchestrated commercialization of the Dutch Cultivation System, the free-trade fanaticism of British Singapore, the 'opening up' of Siam under British pressure following the Bowring Treaty, and the great military mise en valeur of French Indochina, the early episodes in which Asian commerce was restricted or suppressed by European arms seemed inconsequential counter-currents within a larger history whereby the expansion of trade was overwhelmingly associated with European expansion.

\section{A Precolonial Age of Commerce, 1400-1650}

It was Anthony Reid (1988-93, 1990a, 199ob), albeit building on earlier revisionist work on precolonial trade by Meilink-Roelofsz (1962) and others, who at the end of the 1980 s initiated a paradigm shift. Reid presented evidence that a serious economic (and demographic) as well as political crisis took place throughout island Southeast Asia during the period of voc expansion in the seventeenth century, and identified that century as marking the end - not the beginning - of a Southeast Asian Age of Commerce.

During the period $1405^{-1630}$, Reid argued, a long boom in pepper and spice exports to Europe (first via Arabia and the Mediterranean, later via Portugal) and to China led a general expansion of commerce throughout Southeast Asia, triggering in turn a series of new developments in the cultural, social and political spheres. These included mass conversions to Islam in Indonesia, the establishment of the modern Theravada Buddhist orthodoxy in mainland Southeast Asia, the growth of trading cities like Ayutthaya, Malacca and Makassar, and the formation around them of new centralized states financed by trade wealth. Toward the end of this Age of Commerce, the general movement away from local economic autarchy toward commercial exchange and specialization was supported by the emergence of a new pan-regional currency in the form of Spanish American silver imported via the Philippines.

In the mid-seventeenth century, according to Reid, the trade boom ended due to the military conquests and spice monopolies of the voc, together with the threat of further Dutch aggression against polities encouraging non-voc commercial activity. Among the earliest signs of the crisis was the complete disappearance by $165^{\circ}$ of the very large Southeast Asian sailing vessels, efficient but vulnerable to naval attack, which had previously carried much of the region's commerce. Starved of trade income, those major Indonesian states which avoided Dutch conquest (Aceh, Java) declined and fragmented, while 
on the mainland, Burma and Siam retreated defensively from commerce with Europeans. Other factors contributing to the trade slump included internal political problems within the increasingly absolutist indigenous polities, the rulers of which tried, like the voc, to restrict commerce by military means in order to deny economic resources to (actual or potential) rivals.

\section{An Early Age of Commerce, 900-1300}

Recently Wade (2009a), inspired by Reid, has posited another, earlier Southeast Asian Age of Commerce beginning five centuries before Reid's and lasting until about 1300. In many ways, Wade argues, developments during this 'Early Age of Commerce' paralleled and anticipated those of its later counterpart: a boom in maritime trade, the emergence of new ports and urban centres (notably Srivijaya in Sumatra), a movement of existing administrative capitals toward the coast, commercialization, monetization, population expansion, and also religious change, including the first beginnings of the Islamic and Theravada Buddhist expansions which were to bear full fruit during Reid's period.

Triggered by outward-looking trade policies under the Song and Yuan dynasties in China, and by a Chinese 'medieval economic revolution' involving the creation of new forms of money and credit, the maritime trade boom of Wade's Early Age of Commerce was based on the export from Southeast Asia to China of pepper, safflower, fine spices, and forest and marine products, and on the import to Southeast Asia of Chinese ceramics and metals. At the same time Indian Ocean commerce also burgeoned under the auspices of two longdistance maritime trading systems: an Islamic merchant network extending from Arabia to the ports of China, and an almost equally extensive Tamil network emanating from the Chola kingdom on the Coromandel coast of India. The commercial globalization of the period has been highlighted by the recent discovery and excavation in Indonesian waters of five contemporary shipwrecks (including one of a vessel built in India or the Middle East), complete with cargoes including Chinese iron and ceramics, Indian bronzes, and Arabian glass.

Wade links this early globalization with evidence for general economic growth and political change in Vietnam, Champa, and especially Java. Here he draws heavily on earlier work by Jan Wisseman Christie (1993, 1996, 1998, 1999) on Java's role in what she explicitly calls 'the Asian sea trade boom of the tenth to thirteenth centuries'. Java, Wisseman Christie shows, became a sophisticated market economy in this period, attracting many foreign merchant communities and minting its own coins in gold, silver and electrum as well as importing large quantities of copper cash from China. In $929 \mathrm{CE}$, she also notes, the political 
centre of Mataram, Java's dominant state, moved from the landlocked interior of Central Java to a coastal location on the Brantas delta in East Java, where the great fourteenth-century 'empire' of Majapahit would later have its capital. By the time of Majapahit, however, the Early Age of Commerce as defined by Wade had already come to an end around 1300 due to 'stagnation in southeast Asian maritime trade, possibly as a result of the years of warfare the Mongols waged against the southern Song in China, the Yuan efforts to tightly manage maritime trade and the major Yuan military missions launched in the maritime realm' (Wade 2009a:264).

\section{Even Earlier Ages of Commerce?}

Besides describing the Early Age of Commerce avant la lettre, in 1998 Wisseman Christie began to sketch the outline of an even earlier Asian sea trade boom, beginning no later than the seventh century and ending in the ninth, when China 'turned inwards' toward the end of the Tang dynasty. She also pointed to 'hints in the archaeological and early historical records' that ultimately the great trade cycle 'may have had its roots in the later prehistoric period', when Southeast Asia was known in India as a source of gold and precious metals (Wisseman Christie 1998:344).

It is interesting to note that the very early trade boom - if that is what it was which ended in the ninth century coincided with the original cultural Indianization of Southeast Asia, with its Sanskrit (not yet Javanese or Khmer) inscriptions and its 'prototypical' Hindu and Buddhist temples such as those of the Dieng Plateau. This was the era of what Sheldon Pollock has called the 'Sanskrit cosmopolis', when 'Sanskrit literary culture spread across most of southern Asia from Afghanistan to Java', and when the religious, political and artistic ideals of elites throughout that cosmopolis became so similar that 'in the first millennium it makes hardly more sense to distinguish between South and Southeast Asia than between north India and south India' (Pollock 2006:1, 16).

For decades it has been customary to assert that the eastward spread of Indian cultural patterns was the result of Southeast Asian rather than Indian initiative, and did not reflect any kind of 'colonization' by South Asian people, as many once believed (Majumdar 1963). The artistic forms and Sanskrit inscriptions of Indianized Southeast Asia are certainly ambiguous in this respect, being open to Pollock's interpretation as evidence of decentralized cosmopolitanism rather than migrant-borne cultural transmission. Nevertheless we know from the epigraphic record that during the first millennium there were in Southeast Asia diverse communities of Indian traders - one of which even left, in Sumatra and the Malay Peninsula, a series of inscriptions in its own vernacular 
language, Tamil, created in situ over a huge span of time between the third or fourth century and the thirteenth (Guy 2011b).

More importantly, evidence is mounting from genetic research that early immigration from India played a much more important role in the history of Southeast Asia than it has lately been conventional to assume. According to a recent analysis of DNA samples from more than 500 Balinese men, 'approximately $12 \%$ of the Balinese paternal gene pool' is of Indian origin (Karafet et al. 2005:94).

The discovery that about $12 \%$ of Balinese haplogroups are of relatively recent Indian origin and that these haplogroups are rare or absent in neighboring Indonesian islands should prompt a thorough reexamination of the archeological evidence for contact between India and Bali. The genetic evidence we have presented suggests that the magnitude of such trade and other cultural contacts between India and Bali was much greater than has hitherto been imagined.

KARAFET ET AL. 2005:111

A further surprise is that estimates of the antiquity of the Indian genetic input into the Balinese population, derived from the same data, range from 2,6oo to 3,100 years, putting it well before the time of the Sanskrit cosmopolis. The discovery of the tooth of an Indian visitor or immigrant in a Balinese archaeological context from before the beginning of the Common Era confirms the prehistoric origins of direct contact between South and Southeast Asian populations (Lansing et al. 2004).

\section{Colonial and Postcolonial Ages of Commerce in Comparative Perspective}

The identification of at least three major cycles of commercial expansion and contraction in precolonial times places the history of the colonial and postcolonial periods in a radically new light. The great trade boom of the nineteenth and early twentieth centuries, together with the period of financial crisis, war, and political turmoil that followed it after 1930, becomes just one in a long succession of basically comparable cycles, and the renewed regional economic growth and globalization which began around 1970 fits into the same established pattern. Even the cultural aspects of these two most recent cycles can be seen as echoing those of their predecessors - Southeast Asia's current integration into an Anglophone global cosmopolis, for instance, parallelling in some ways the participation of its elites in the Sanskrit cosmopolis of the first millennium. 
It is striking that when the successive Ages of Commerce are tabulated chronologically alongside the intervening crises (Table 8.1), Southeast Asia's history is seen to consist predominantly of the former. Taken together, the crises of the ninth, fourteenth, (long) seventeenth and (short) twentieth centuries occupy just over one quarter of the last 1400 years. The other three quarters fall within periods of relative commercial openness and growth, indicating that in the very longue durée, the Southeast Asian past is dominated by a secular trend of commercialization.

Nevertheless it would be misleading to exaggerate either the cumulative nature of this process, or the mutual comparability of the various commercializing phases. If the nineteenth century was not Southeast Asia's first Age of Commerce, in terms of sheer scale and value of trade it still represented an unprecedented change. In 1998 Reid and a number of colleagues published a slim yet monumental compilation of statistics on exports of four major Southeast Asian commodities - cloves, pepper, coffee, and sugar - to other parts of the world from the fourteenth century to the twentieth. When the total value (corrected for inflation) of all four is plotted graphically by decade (Figure 8.1), it is clear that by far the fastest export growth took place during the nineteenth century, and that compared with the level of exports reached by

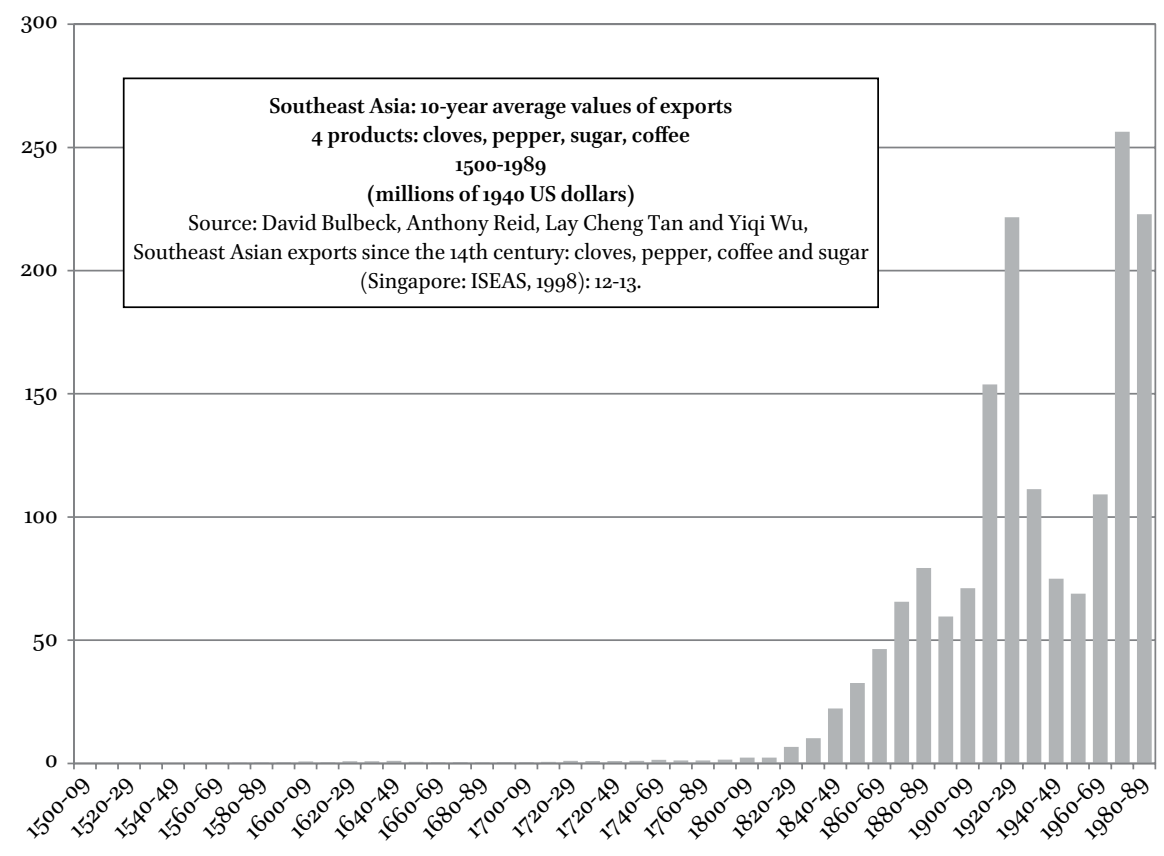

FIGURE 8.1 Southeast Asian exports, 1500-1990 


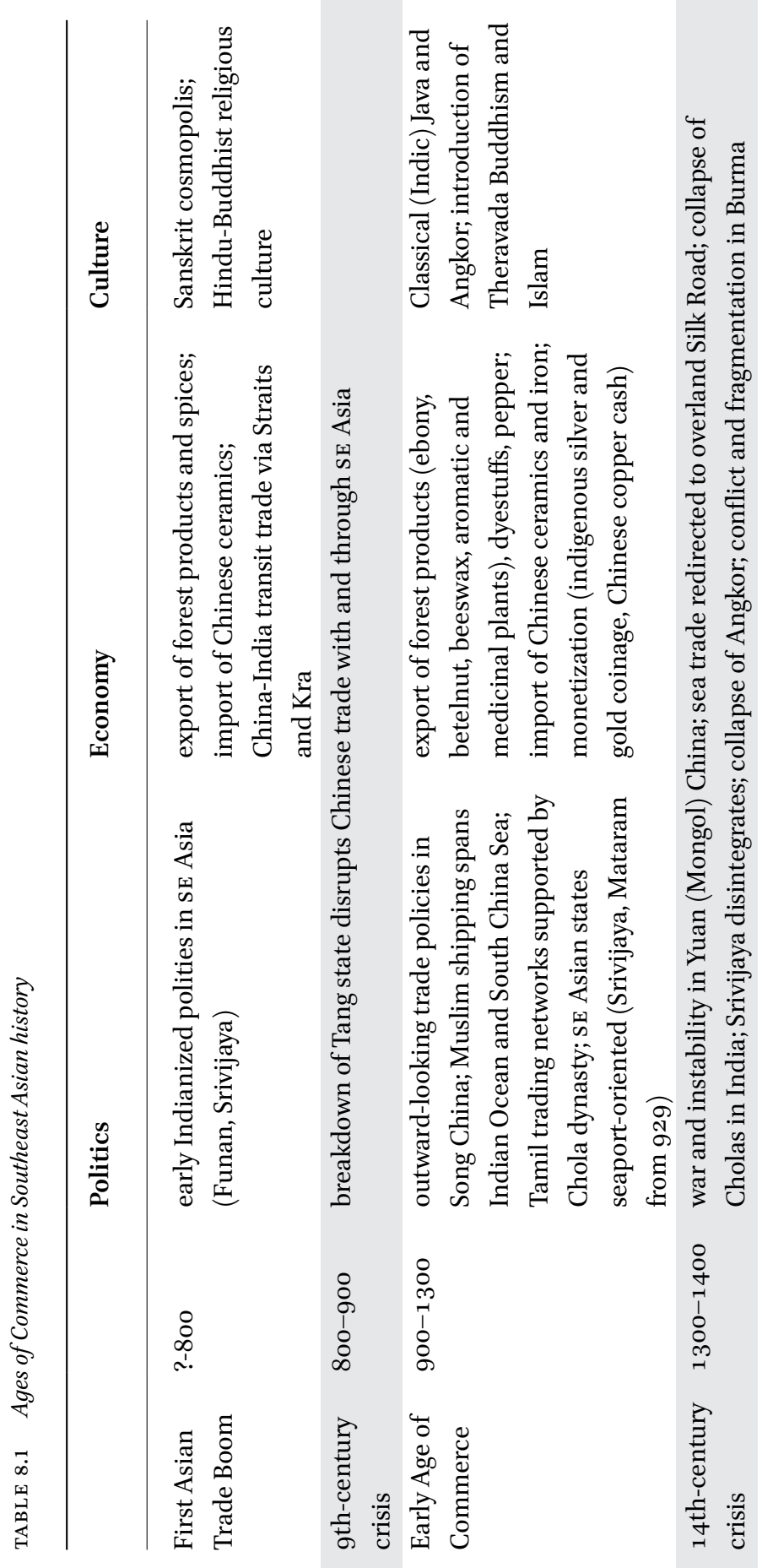




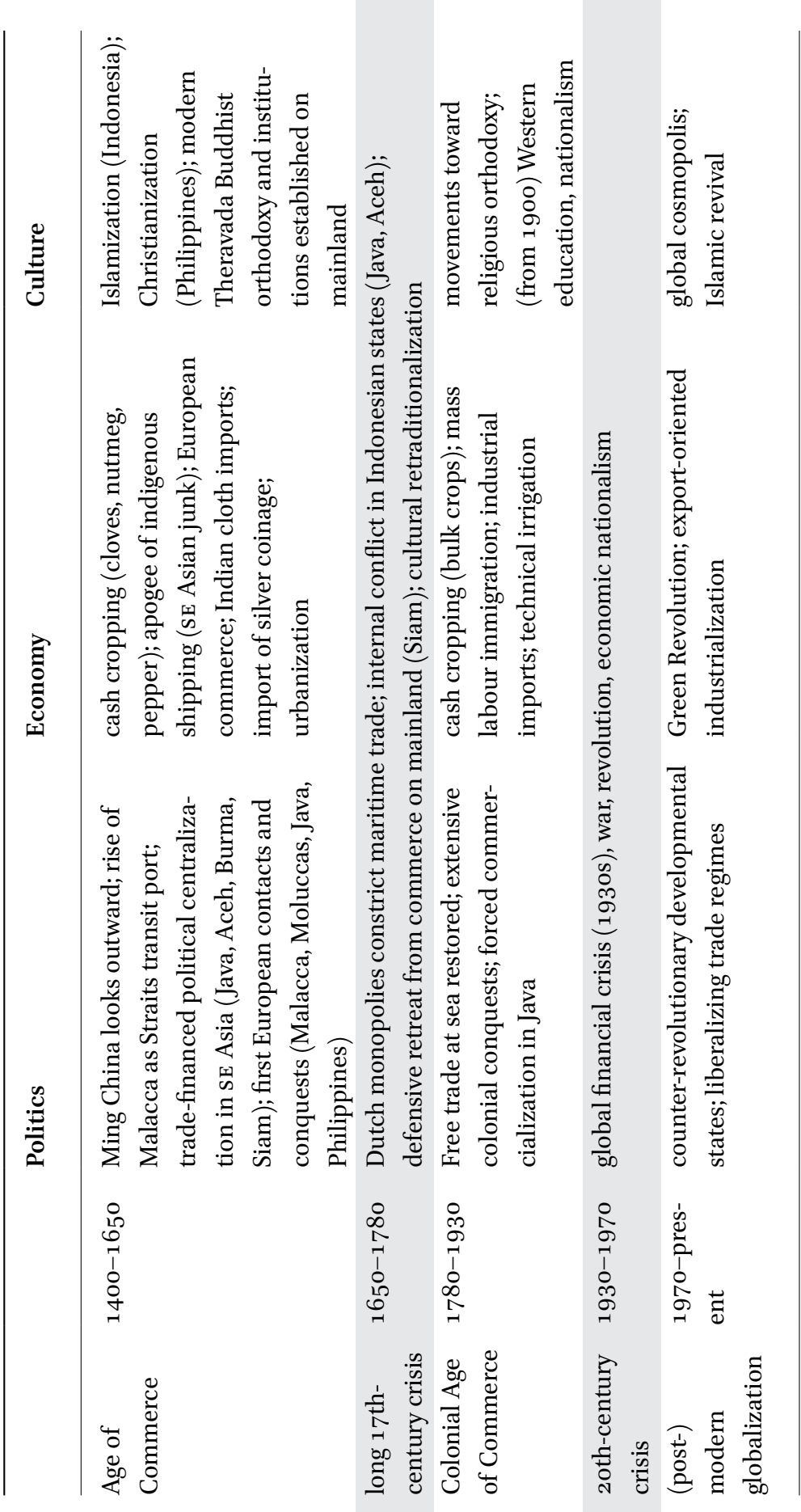


1900, those achieved during the last precolonial Age of Commerce, even at its peak in the 1640s, shrink into insignificance. Since population also grew in the nineteenth century, the contrast with respect to the four selected commodities would be somewhat less dramatic if their value was calculated on a per capita basis. On the other hand the difference in absolute value would be even greater if important new export products of the late colonial period, such as copra, rubber and oil, were included in the statistics.

\section{Limitations of the Paradigm}

One disadvantage of the Ages of Commerce paradigm, then, is its tendency to mask the novelty, at least in a quantitative sense, of what happened in the nineteenth century and after. Reid (1998b:15) highlights the fact that within the colonial period, the rate of export growth was higher in the period 1780-1870, when Southeast Asia's export crops were still produced almost exclusively by small farmers, than in the decades of 'high colonialism' after 1870, when big European-owned plantations became significant. In so far as the trade boom of this period was underpinned by the ability of Southeast Asian peasants to seize commercial opportunities, there was indeed continuity here with earlier Ages of Commerce. Nevertheless, the colonial era in Southeast Asia was clearly a revolutionary one in economic terms. Besides production for export on a scale much more comparable with the twenty-first century than with anything prior the nineteenth, it also saw movements of capital and labour to and within Southeast Asia on a scale which, after the crisis of 1930, was not to be seen again for more than 50 years (Amrith 2011:29-49, 151; Lindblad 1998:24).

Reid (1998b:15) dates the onset of the trade recovery, following the crisis of the long seventeenth century, to the 'collapse of Company control' and the beginning of British naval ascendancy around 1780 . This is consistent with his portrayal of the previous Age of Commerce as having been possible thanks to an environment of free trade, and having ended largely because of the voc's endeavour to monopolize the sea lanes and control the production of the most valuable export goods. However it is worth noting here that during the period of very rapid growth in Southeast Asian exports in the middle of the nineteenth century, a large proportion of that growth was accounted for not by free peasant enterprise, but by the compulsory (albeit not necessarily unprofitable for the cultivator) production of sugar and coffee by an unfree peasantry under the Cultivation System in Dutch Java (Reid 1998b:13, 123-124, 152-153).

A more fundamental criticism of the paradigm is that as far as the period prior to the nineteenth century is concerned, the propositions advanced in the 
Ages of Commerce literature are based on weak statistical foundations. Reid and his colleagues do an admirable job of bringing together what scattered quantitative data do exist on Southeast Asian spice exports, and silver and cloth imports, in the early modern period. But is difficult to avoid the suspicion that the figures they synthesize still represent only a fragment of reality, and that the trends they infer often reflect changes in the coverage and accuracy of their sources rather than real changes in economic conditions. Some of the population figures cited by Reid to support the idea of a seventeenth-century demographic crisis, consisting of crude household counts compiled for taxation purposes, are almost certainly so unreliable as to be useless for historical purposes (Henley 2005a:115-116).

Even allowing for statistical understatement, the limited quantity and value of precolonial long-distance trade remains disconcerting given its alleged historical significance. The further we go back into the past, not surprisingly, the more striking this discrepancy becomes. The best-known objects of (probable) South Asian origin found in Southeast Asian archaeological sites dating from the eve of the Sanskrit cosmopolis are fragments of a type of pottery known as 'rouletted wares', sometimes used as a marker of Indian Ocean trade. Manguin (2011:xxi) notes that if all the shards of this ware ever found in Southeast Asia, representing some four centuries of commerce, were put together, they would make up 'enough whole dishes to set tables for only five dozen people'. While far greater numbers must of course have disappeared in the intervening 2,000 years, such a statistic still seems more in line with the old anthropological paradigm of 'prestige goods exchange' than with any economic model of Indian Ocean commerce.

Although the long-distance trade of the medieval and early modern Ages of Commerce was undoubtedly more intensive, it remains hard to disagree with Van Leur's well-known assessment that most of the commodities involved were still 'splendid and trifling': incense, dyestuffs, spices, porcelain, silver. Could their transport and exchange really have had the profound historical implications claimed for them: the rise and fall of states, economies, populations, religions? And if commerce played such a central role in cultural change, then how to explain the feeble cultural influence of China on Southeast Asia (except Vietnam) over a millennium of Chinese trade and immigration? Or the fact that the modern religious institutions of Burma, Thailand, Laos and Cambodia have their origins in Sri Lanka, a country not known to have traded intensively with Southeast Asia? These puzzles raise fundamental questions of causation. Did the trade cycle really cause the other changes associated with it? If so, what drove the trade cycle? If not, why the apparent synchronicity? Was there some other motor that powered them all? 


\section{Lieberman's Critique}

Although he claimed it was also applicable to parts of the mainland, particularly Thailand, Reid's Age of Commerce thesis was developed mainly in relation to the maritime realm of island Southeast Asia (present-day Indonesia, Malaysia, and to a lesser extent the Philippines), which he knew best and for which the best early data existed. It was soon to be contested by the doyen of mainland Southeast Asian historical studies, Reid's counterpart Victor Lieberman (1995, 2003, 2009, 2010).

Lieberman found little evidence in Burma, Thailand or Vietnam for Reid's seventeenth-century crisis. Here the decline in European trade during that century was compensated by growing Chinese commerce, and the major states became stronger rather than weaker between $165^{\circ}$ and $175^{\circ}$ (Lieberman 1995:801-803). At least in terms of political disintegration, however, three other major crises were clearly discernible on the mainland. These occurred in the fourteenth century, which saw the demise of the classical empires of Angkor and Pagan; in the late sixteenth, when the main kingdoms in Burma and Thailand both briefly collapsed; and in the mid-eighteenth, when conflict and revolt (including the Tay Son rebellion in Vietnam) overtook the whole peninsula. Of the three mainland crises only one, that of the fourteenth century, clearly corresponded to events in the islands, where it coincided with the fall of Srivijaya - although Majapahit, further east, was temporarily able to benefit from the resulting power vacuum by strengthening its influence over the Spice Islands (Wisseman Christie 1993:4-5). All three, on the other hand, seem to have surprising echoes in much more distant parts of Eurasia, including France, Russia, and to some extent Japan (Lieberman 2003:3, 4; 2009:58-62).

International trade cycles, Lieberman argues, cannot in themselves explain these patterns. This is not only because mainland Southeast Asia was for most of its history much less commercialized than the islands - astonishingly, the great medieval empire of Angkor, in sharp contrast to contemporary Java, was still 'a society without money' (Lustig 2009:88) - but also because commercial links with Europe and Japan were simply too tenuous, at most of the periods in question, to provide a convincing explanation for the observed cyclic coordination.

Lieberman's own theory, reduced to essentials, is as follows. First, big polities throughout Eurasia were individually subject to an endogenous cycle of expansion and decline caused in the ecological sphere by a cycle of agricultural intensification, population growth, and overpopulation; and in the political sphere by a cycle of territorial overexpansion and fragmentation, combined perhaps with 'an inherent tendency toward dynastic cyclicity', whereby 'an initially successful dynasty was obliged to tolerate the accumulation of resources 
by political or religious elites on whom it depended', but who eventually usurped its power (Lieberman 2003:369). The reasons why these cycles became more or less synchronized across the continent, secondly, included intellectual and technological diffusion, disease dynamics, and Central Asian politics, as well as international commerce (Lieberman 2009:77-92). Perhaps the most important reason, however, was climatic change.

\section{Nature as Pacemaker?}

Not all environmental forces shape human history only as steady constraints in the longue durée; some are themselves subject to change over historical time. Reid (199ob:654-656) already suggested that climatic variation, in the form of a series of very dry years in the 1650 s and 60 s - confirmed by evidence from growth rings in teak trees from Java - exacerbated the crisis of the seventeenth century by causing poor harvests, famine, and epidemics. Lieberman (2003:239240) took this further by drawing on work by physical geographer David Godley to argue that the collapse of Angkor and Pagan in the fourteenth century was caused partly by a 'general desication of Indochina' (Godley 1997:142), coinciding with the end of the 'medieval warm period' in Europe, when England produced wine and Greenland was settled by Vikings. Recent dendrochronological research on teak and other deciduous trees from Burma, Thailand and Vietnam confirms that periods of repeated drought and climatic instability coincided not only with the fourteenth-century crisis (Buckley et al. 2010), but also with the political crises of the mid-eighteenth century (D'Arrigo et al. 2011:4).

In Table 8.1, the rhythm of the Ages of Commerce and the intervening crises appears to be set mainly by political events (such as dynastic changes and wars) originating outside Southeast Asia in China, India, and (in the case of the seventeenth-century voc intervention) the West. But advances in climate history may yet show that most of those events are themselves related, via ecological, demographic, and economic intermediary mechanisms, to an underlying rhythm of climatic change that acts as the global pacemaker of human history.

Besides climate change, other important environmental events influencing the course of human history include the volcanic eruptions, earthquakes and tsunamis which Indonesians in particular are once more all too familiar with in the early twenty-first century. Belonging in a sense more to Braudel's histoire événementielle than to the longue durée, these can in fact be more sudden and intermittent in their effects than any war or economic crisis, yet at the same time so violently destructive that their after-effects may last for decades, or even longer. Recently, Reid (2012) has used a combination of 
geomorphological evidence, uncovered by research stimulated by the 2004 Aceh tsunami, and historical sources to suggest that hitherto unsuspected tsunami disasters were involved in both the seventeenth- and fourteenth-century economic and political crises. The idea that such a critical watershed in Indonesian history as the transition from Indianization to Islamization, which transition is arguably one dimension of the fourteenth-century crisis, can be explained partly by a combination of climate change and tsunamis is for most people - specialists included - a new, radical, and intriguing one. Along with experts in historical genetics, environmental scientists, using radiocarbondated material from coral reefs and beach deposits to reconstruct seismic and tsunami events, and data from tree rings to reconstruct climate change, are now at the forefront of research into the history of Southeast Asia in the longue durée.

\section{Conclusion}

The aim of this chapter has been to provide a brief critical survey of the development, implications, and limitations of the Age of Commerce paradigm for the study of Southeast Asian history. The idea of an Age of Commerce, initially proposed by Anthony Reid to characterize the period 1400-1680, has been a fertile one, prompting both a search for parallels with other periods and an extensive critique of Reid's chronology and conclusions, particularly in relation to mainland Southeast Asia. The economic and demographic evidence informing this debate is often surprisingly weak, and those statistics which do exist suggest that quantitatively speaking the long-distance commerce of Reid's and earlier periods, whether measured by volume or by value, never amounted to more than a tiny fraction of what Southeast Asia was to export and import in the nineteenth and twentieth centuries. Nevertheless, the evolving debate over the Age of Commerce paradigm has had many benefits for our understanding of Southeast Asia. It has, for instance, confirmed that openness to commerce and globalization has been characteristic of the region, and particularly of maritime Southeast Asia, throughout most of its history. It has helped to undermine oversimplified dichotomies between colonial and precolonial situations which have often led the impact of Europe on Southeast Asia to be exaggerated or misunderstood. It has helped to draw attention to the importance of environmental forces, including climate change and seismic events, in shaping Southeast Asian history. And it has contributed to the general, pervasive awareness of the longue durée and its patterns which is reflected in the work of influential contemporary Southeast Asianists such as Peter Boomgaard. 